\title{
Risk factors associated with small-ruminant lentiviruses in sheepfold buildings
}

\author{
Wiktor Bojar ${ }^{1, A-B, D, F}$, Andrzej Junkuszew ${ }^{1, A-B, D}$, Paulina Dudko, ${ }^{1, D}$, Monika Olech ${ }^{2, B}$, \\ Zbigniew Olesiński ${ }^{3, C}$, Tomasz Gruszecki ${ }^{1, E}$, Jacek Kuźmiak ${ }^{3 \mathrm{E}}$ \\ ${ }^{1}$ University of Life Sciences, Lublin, Poland \\ 2 Department of Biochemistry, National Veterinary Research Institute, Pulawy, Poland \\ ${ }^{3}$ Department of Hygiene of Animal Feedingstuffs, National Veterinary Research Institute, Pulawy, Poland \\ A - Research concept and design, B - Collection and/or assembly of data, C - Data analysis and interpretation, \\ $D$ - Writing the article, E - Critical revision of the article, F - Final approval of article
}

Bojar W, Junkuszew A, Dudko P, Olech M, Olesiński Z, Gruszecki T, Kuźmiak J. Risk factors associated with small-ruminant lentiviruses in sheepfold buildings. Ann Agric Environ Med. 2018; 25(3): 383-387. doi: 10.26444/aaem/92149

\begin{abstract}
Introduction. Small-ruminant lentivirus (SRLV) infection is widespread across Europe. It causes substantial economic losses in sheep breeding. The main route of SRLV infection is through the mother's milk, especially colostrum However, infection can also occur via contact between infected and healthy animals. It should be noted that the mechanisms of contact infection are still relatively poorly understood. The virus can also spread through a flock via an aerogenic mechanism.

Objective. Due to the increased risk of SRLV infection in sheep bred in an alcove system, this study sought to define the effect of various selected factors associated with alcove breeding on the frequency of SRLV infection in sheep

Materials and method. Risk factors associated with small-ruminant lentivirus (SRLV) infection were analyzed among flocks of sheep in central-eastern Poland. Ninety-eight sheep flocks were selected for detailed investigation and included 6,470 ewes and 15 breeds and lines. Serologic testing of blood samples was used to identify infected animals and evaluate the epidemiologic status of particular flocks. Specific antibodies for Maedi Visna Virus (MVV) were detected via ELISA. Questionnaires were used to gather information concerning risk factors.

Results. The study's results indicate that factors associated with environmental conditions under which sheep are kept play a significant role in determining the risk of SRLV infection.

Conclusions. Special attention should be focused on airborne contamination associated with the technologies used in sheep breeding. Breeding technologies that limit airborne contamination in farm buildings should be employed. In developing programmes to eliminate SLRV in sheep flocks, improvement of zoohygenic conditions should also be considered.
\end{abstract}

\section{Keywords}

risk factors, lentivirus, source of infection

\section{INTRODUCTION}

Small-ruminant lentivirus (SRLV) infection is widespread across Europe and causes substantial economic losses in sheep breeding $[1,2]$. SRLV infection is characterized by a relatively long period of incubation. The symptoms are rarely observed in lambs but intensify with age $[3,4]$.

The most successful method for preventing the spread of the virus in sheep flocks is to eliminate SRLV-seropositive individuals and replace them with SRLV-free animals. This method was successfully applied in Iceland. Unfortunately, this method of SRLV elimination is not only costly, it also reduces the genetic potential of flocks, which in some cases may have taken many years of selection to form $[5,6,7]$. The potential for negative economic impact represents a significant problem in the introduction of programmes aimed at eradicating SRLV and has been discussed by many authors $[8,9]$. In addition to the above-mentioned factors, those that promote the spread of viruses in sheep flocks, should also be considered in the development of new SRLV elimination programmes.

Address for correspondence: Wiktor Bojar, University of Life Sciences in Lublin, Akademicka 13, 20-950 Lublin, Poland

e-mail:w.bojar@o2.pl

Received: 16.11.2017; accepted: 11.06.2018; first published: 13.07.2018
The main route of SRLV infection is through the mother's milk, especially colostrum [10, 11]; however, infection can also occur via contact between infected and healthy animals. It should be noted that the mechanisms of contact infection are still relatively poorly understood. Some authors have suggested that water contaminated by the saliva or nasal discharges of infected sheep is one channel for contact spread $[12,13,14]$. The virus can also spread through a flock via an aerogenic mechanism. As claimed by Leginagoikoa et al. (2006), minimizing crowding and improving the ventilation in animal housing facilities can decrease the risk of SRLV infection in sheep. Unfortunately, to-date, factors directly associated with animal welfare have gained little attention. The significance of these factors, however, is demonstrated by the higher frequency of SRLV infection in flocks of sheep bred in closed sheepfolds, compared with flocks bred under semi-intensive conditions involving the use of pastures [15].

\section{OBJECTIVE}

Due to the increased risk of SRLV infection in sheep bred in an alcove system, this study sought to define the effect of various selected factors associated with alcove breeding on the frequency of SRLV infection in sheep. 


\section{MATERIALS AND METHOD}

Animals. Selected risk factors associated with SRLV infection were analyzed among flocks of sheep from central-eastern Poland. Ninety-eight flocks were selected for detailed investigation and included 6,470 ewes and 15 breeds and lines of sheep: Polish Merino (3.49\% of the tested head age), Polish Lowland (3.76\%), Wielkopolska (2.76\%), Zelazna (0.21\%), Uhruska (57.28\%), Olkuska (2.39\%), Polish Heath (0.72\%), Swiniarka (4.62\%), Polish Mountain (3.01\%), Podhale Zackel (1.06\%), Blackheaded Mutton (2.60\%), Ile de France (2.91\%), Berrichone du Cher (3.56\%), synthetic prolific meat line BCP (7.01\%), and SCP (4.62\%). In this breed structure, the Urhuska predominated. When selecting the flocks, it was determined that all the breeds would be represented in the under study group.

Data collection. On the day blood samples were collected from the animals, the farmers were individually interviewed by the research team using an own prepared questionnaire. The questionnaires included both open and close-ended questions. The aim of the questionnaire was to evaluate potential risk factors conducive to the spread of SRLV in sheep flocks, such as the construction material used for livestock buildings, the area per ewe, feeding technology, the presence of a forage passage, the place forage is stored, material used for the livestock building roofing, factors affecting animal welfare (deep/shallow litter, grillage technology), and the frequency of manure removal. The condition of the buildings was evaluated on a 5-point scale (1-very bad, 2-bad, 3- moderate, 4-good, 5-very good).

The manager of every flock evaluated in the study was affiliated with the Regional Union of Sheep and Goat Breeders (RASGB), which supervises breeding work on the farms. Additional information useful for the analyses and results interpretation of the study, including the animals and their turnover in the studied flocks, was gathered from information provided by the RASGB.

Choice of sampling strategy. The flocks were stratified for analysis $[16,17,18]$. The aim was to define the factors that are conducive to the spread of lentivirus infections in sheep, without the need to examine all of the animals. This made it possible to plan the number of samples taken, taking into consideration the analytical possibilities as they related to the structure of a given flock characteristic to the region being researched, and the accuracy assumed in advance, which would reflect the measurement error. In order to improve the effectiveness of the stratification, a multistage cluster sampling scheme was applied. The flocks were divided into groups (called 'clusters') based on size: small (1-11 individuals), medium (12-100 individuals), and large (>100 individuals). How many animals should be examined from the flocks within a particular cluster was then calculated. It was assumed that in order to reveal all seropositive flocks in the study, the accuracy of determinations of the level of infection within a flock would have to be no less than $8 \%$, regardless of its size.

A total of 2,925 sheep were singled out for serum sampling from the overall population of 6,470 ewes bred in 98 brood flocks of different sizes. The percentage of animals within a particular flock from which serum samples were taken differed and depended on the flock size. For example, as a result of stratification, in small flocks (up to 11 sheep), serum from all of the animals was examined, whereas in large flocks (>100 animals), serum from $30 \%$ of the sheep in the flock (chosen randomly) was analyzed.

Seroepidemiologic analyses. The identification of infected animals and the epidemiological assessment of each flock was made based on serological tests of blood serum samples. Detection of specific antibodies against MVV was performed using a commercially available ELISA test (MAEDI VISNA/ CAEV verification, IDEXX, Montpellier, France), according to the manufacturer's recommendations. This test was based on indirect ELISA which uses an immunogenic peptid of a transmembrane protein and the recombinant $\mathrm{p} 28$ protein which enters into the composition of the viral capsid. Sensitivity and diagnostic specificity of this ELISA kit are $99.8 \%$ and $99.7 \%$, respectively.

Risk factor model development. In order to identify the primary animal welfare and environmental condition risk factors impacting the spread of lentivirus infections in sheep and to define the pathways by which viruses of this type spread, odds ratio (OR) were calculated. The OR represented a universal measurement for defining and comparing the impacts of particular risk factors. The chi-square test was used to determine the significance of differences in proportions, and the Mantel-Haenszel test was used for corrected risk analyses. The data were analyzed using the programme 'R', module 'epir' [19]. Calculations of point estimates and confidence intervals were based on equations reported by Rothman (2002) [20] and Jewell (2004) [21].

\section{RESULTS}

Various factors that could affect the risk of SRLV infection in flocks of sheep from central-eastern Poland were evaluated in the present study. Table 1 presents the results of analyses of factors associated with livestock buildings. The material used to build the sheepfolds did not significantly increase the risk of lentivirus infections in the flocks $(\mathrm{OR}<1 ; \mathrm{p}>0.05)$. Similar results were obtained with respect to the condition of the buildings. However, it was observed that SRLV infection risk increased with an increase in area per ewe (OR 3.58 $[95 \%$ CI 2.5, 5.12]). It is worth noting that in flocks where the area per ewe was $\geq 5 \mathrm{~m}^{3}$, the prevalence was $12.95 \%$, whereas in other flocks it was lower (3.99\%). The technology used for animal maintenance had a considerably greater impact on the increase in SRLV infection risk. The absence of a forage passage significantly increased the risk index OR, which in this case was 2.11 (95\% CI 1.55, 2.88). Importantly, the prevalence in flocks which had no forage passage was almost twice that in flocks kept in sheepfolds with a passage (11.92\% vs. $6.03 \%)$. Storage of forage in the sheepfold attic also significantly impacted the risk of infection (OR 1.82 [95\% CI 1.43, 2.33]; $\mathrm{p}<0.0001)$. The prevalence for sheepfolds in which large amounts of forage were stored in the attic was $13.05 \%$, vs. $7.61 \%$ for buildings without an attic. The material used to construct the sheepfold roof covering was also examined. It was observed that the use of a material other than metal sheeting to cover the roof could increase the lentivirus infection risk (OR 1.86 [95\% CI 1.27, 2.74]). A negative influence of asbestos roof covering was also found 
(OR 2.48 [95\% CI 1.82, 3.36]). It should be noted that in all the cases discussed in which a significant association was found, the p-values were $\leq 0.001$.

As shown in Table 1, the use of deep litter for sheep breeding also significantly increased the risk of SRLV infection in the flocks observed (OR 5.99 [95\% CI 3.48, 10.33]). The prevalence of infection was more than 5 times higher in flocks in which animals were bred in deep litter versus those in which animals were bred in shallow litter.

Table 1. The influence of factors associated with sheepfold buildings and breeding technology on the increase in SRLV infection risk

\begin{tabular}{|c|c|c|c|c|c|c|}
\hline \multirow[t]{2}{*}{ Risk factor } & \multirow[t]{2}{*}{ Category } & \multicolumn{2}{|c|}{$\begin{array}{c}\text { MVV } \\
\text { seropositivity }\end{array}$} & \multirow[t]{2}{*}{$\mathrm{OR}(\mathrm{Cl})$} & \multirow{2}{*}{$\begin{array}{l}\text { Prev. } \\
(\%)\end{array}$} & \multirow[t]{2}{*}{ p-value } \\
\hline & & $(+)$ & $(-)$ & & & \\
\hline \multirow{2}{*}{$\begin{array}{l}\text { Type of } \\
\text { building }\end{array}$} & Wooden & 41 & 439 & \multirow{2}{*}{$\begin{array}{c}0.8 \\
(0.56,1.12)\end{array}$} & 8.54 & \multirow{2}{*}{0.192} \\
\hline & Brick and other & 257 & 2188 & & 10.51 & \\
\hline \multirow{2}{*}{$\begin{array}{l}\text { Building } \\
\text { condition }\end{array}$} & $\begin{array}{l}\text { Moderate, bad, } \\
\text { and very bad }\end{array}$ & 131 & 1289 & \multirow{2}{*}{$\begin{array}{c}0.81 \\
(0.64,1.04)\end{array}$} & 9.23 & \multirow{2}{*}{0.094} \\
\hline & $\begin{array}{l}\text { Good and very } \\
\text { good }\end{array}$ & 167 & 1338 & & 11.10 & \\
\hline \multirow{2}{*}{ Area per ewe } & $\geq 5 \mathrm{~m}^{2}$ & 262 & 1761 & \multirow{2}{*}{$\begin{array}{c}3.58 \\
(2.5,5.12)\end{array}$} & 12.95 & \multirow{2}{*}{$<0.0001$} \\
\hline & $<5 \mathrm{~m}^{2}$ & 36 & 866 & & 3.99 & \\
\hline \multirow{2}{*}{$\begin{array}{l}\text { Sheepfold } \\
\text { with a forage } \\
\text { passage }\end{array}$} & No & 246 & 1817 & \multirow{2}{*}{$\begin{array}{c}2.11 \\
(1.55,2.88)\end{array}$} & 11.92 & \multirow{2}{*}{$<0.0001$} \\
\hline & Yes & 52 & 810 & & 6.03 & \\
\hline \multirow{2}{*}{$\begin{array}{l}\text { Storing } \\
\text { forage in an } \\
\text { attic }\end{array}$} & Yes & 181 & 1206 & \multirow{2}{*}{$\begin{array}{c}1.82 \\
(1.43,2.33)\end{array}$} & 13.05 & \multirow{2}{*}{$<0.0001$} \\
\hline & No & 117 & 1421 & & 7.61 & \\
\hline \multirow[t]{2}{*}{ Roof cover } & $\begin{array}{l}\text { Asbestos- } \\
\text { cement } \\
\text { covering }\end{array}$ & 267 & 2160 & \multirow[t]{2}{*}{$\begin{array}{c}1.86 \\
(1.27,2.74)\end{array}$} & 11.00 & \multirow[t]{2}{*}{0.0013} \\
\hline & metal sheets & 31 & 467 & & 6.22 & \\
\hline \multirow[t]{2}{*}{ Type of litter } & Deep & 284 & 2028 & $\begin{array}{c}5.99 \\
(3.48,10.33)\end{array}$ & 12.28 & $<0.0001$ \\
\hline & Shallow & 14 & 599 & & 2.28 & \\
\hline \multirow[t]{2}{*}{$\begin{array}{l}\text { Frequency } \\
\text { of manure } \\
\text { removal }\end{array}$} & $\begin{array}{l}\text { Once per year/ } \\
\text { less frequently }\end{array}$ & 207 & 1331 & $\begin{array}{c}2.21 \\
(1.71,2.87)\end{array}$ & 13.46 & $<0.0001$ \\
\hline & $\begin{array}{l}\text { Twice per } \\
\text { year and more } \\
\text { frequently }\end{array}$ & 91 & 1296 & & 6.56 & \\
\hline
\end{tabular}

The risk index was also influenced by the frequency of manure removal from the sheepfold. In flocks in which the manure was removed only once per year, the SRLV infection risk was higher (OR 2.21 [95\% CI 1.71, 2.87]; p<0.0001).

\section{DISCUSSION}

The health of sheep used in breeding has a significant influence on the end economic benefit $[22,23,24,25,14,26]$. One factor that significantly impacts animal health is the conditions inside the animal housing facility. Inappropriate climate conditions and/or air contamination inside the livestock building can adversely affect animal health, resulting in a loss in productivity [27].

This study evaluated a variety of factors that can affect the risk of SRLV infection in sheep. As the results reveal, one factor that can significantly increase the risk of lentivirus infection is the means of feeding. In farms lacking a forage passage, the risk was definitely higher. The absence of a forage passage provided more space for the sheep to move around, thus potentially increasing the amount of airborne dust in the buildings. This link was supported by the higher observed risk of SRLV in sheepfolds with more space per ewe. This information, along with the increased risk of SRLV infection in those flocks in which forage, such as hay and straw, was stored in the attic directly above the animals, suggests that the increased risk could be due to levels of airborne contamination in the sheepfolds. Cambra-López et al. [28] drew attention to the fact that airborne particulate matter is considered the primary factor associated with poor air quality in livestock buildings. The primary sources of airborne contamination are forage, litter, and dried animal excrement, which is consistent with the observations of the present study. Storing forage in an attic is, on the one hand, beneficial for the general thermal balance in the sheepfold, as it serves as an insulating material, but on the other hand, it constitutes an and in many cases it is a cause of worsening animal health. It presume that this situation could be caused by a larger dust in sheepfolds. This has been demonstrated by other authors, who drew attention to airborne contamination as a significant threat to the health of animals and people working with them. The dangers of airborne contamination are primarily associated with toxic compounds and fungal spores that may be present in the contaminated air $[29,30]$. It must be stressed that inhalation of airborne contaminants can be particularly dangerous, as demonstrated by numerous epidemiologic studies [31, 32, 1]. As Danuser et al. [33] observed, farmers attending animals in buildings with high levels of airborne contamination are susceptible to more frequent episodes of chronic bronchitis. This factor is also significant for the animals, as high levels of airborne contamination can cause illnesses of the respiratory system in them as well [34].

The risk of health problems caused by airborne contamination is related to the size of the airborne dust particles. The effects are more severe for tiny and very tiny particles, as they can penetrate deeper into the respiratory tract and reach the air sacks where they may induce inflammation [35]. As indicated previously, organic dust in livestock buildings can contain a variety of substances, such as plant particles, animal pelage, urine, excrement, and microorganisms. Organic dust can also facilitate the spread of bacteria and pathogenic viruses harmful to both human and animal health. Penetration of microorganisms into the respiratory tract can be exacerbated by damage to respiratory tissues caused by ammonia in livestock buildings, which can be adsorbed onto dust particles [36]. It should be noted that live bacteria and viruses in contaminated air can have a high survival capability, which favours the spread of infections [37, 38]. Collectively, these data provide a considerable amount of information concerning the role livestock building conditions play in SRLV infection risk. Both the lack of a forage passage and forage storage conditions influence the level of airborne contamination in livestock buildings. It should also be noted that breeding sheep in deep litter (which can increase the amount of ammonia in the air) is also conducive to the spread of lentivirus infections, as microorganisms can survive longer in the upper layers of deep litter, primarily due to favorable humidity and temperature conditions [39].

The current analyses of the effect of the type of roof covering in sheepfolds demonstrate the significant 
impact of environmental conditions, including airborne contamination, on the risk of lentivirus infection. The risk decreases if the roof is covered with metal sheeting (i.e., material with a smooth surface). As reported by various authors, surface porosity affects the settling of dust and humidity. Moreover, surfaces with higher porosity can facilitate the survival of bacteria and viruses. An example of such a material pertinent to this study is asbestos. Asbestos is a very popular material used for roof construction in Eastern Europe [40]; however, due to its known adverse health effects, particularly for humans, the European Union ordered that it should be removed by 2032, a process that is currently ongoing. The danger of asbestos results primarily from its corrosion due to atmospheric conditions and mechanical damage. In such cases, respirable fibers are released into the atmosphere, which can cause respiratory system damage if inhaled [41]. A significant characteristic of asbestos is its high porosity, which increases when it is damaged. The resulting pores can be ideal places for dust to settle, and this dust can carry pathogenic microorganisms $[37,38,35]$. The results of the presented study demonstrate that the risk of lentivirus infection in sheep is significantly higher in animals housed in livestock buildings with asbestos roof covering.

\section{CONCLUSIONS}

The results of the presented study indicate that environmental factors associated with the housing facility significantly affect the risk of SRLV infection in sheep. Special attention should be given to technologies used in sheep breeding and how these technologies affect airborne contaminant levels. In animal husbandry, only those technologies that will substantially limit levels of airborne contaminants in livestock buildings should be employed. In developing future programmes aimed at eliminating SRLV infections in sheep, improvements in the zoohygenic conditions of the flock of sheep being bred should also be taken into consideration.

\section{Acknowledgements}

This study was supported by Project No. NN 311609638. The authors express their thanks to David Robinette, $\mathrm{PhD}$. from ScienceDocs Inc. for language editing.

\section{REFERENCES}

1. Arsenault J, Dubreuil P, Girard CH, Simard C, Belanger D. Maedi-visna impact on productivity in Quebeck sheep flocks (Canada). Prev Vet Med. 2003; 50: 125-137.

2. Junkuszew A. Growth and slaughter value of lambs from a maedi visna virus infected sheep flock. Monograph Rozprawy Naukowe UP w Lublinie 344 WUP Lublin 2010.

3. Lipecka Cz, Kuźmak J, Junkuszew A, Kozaczyńska B, Gruszecki TM. The Relations between breed and age associated susceptibility/ resistance of sheep infection with meadi visna virus (MVV). Arch Tierz. Dummerstorf 2006; 49; 160-165.

4. Narayan O, Cork LC. Lentiviral diseases of sheep and goats: Chronic pneumonia leukoencephalomyelitis and arthritis. Rev Infect Dis. 1985; 7: $89-98$.

5. Lujan L, Begara I, Collie DDS, Watt NJ.. Ovine lentivirus (maedi-visna virus) protein expression in sheep alveolar macrophages. Vet Path. 1994; 31: 695-703.

6. Blacklaws BA, Berriatua E, Torsteinsdottir S, Watt NJ, de Andres D, Klein D, at al. Transmission of small ruminant lentiviruses. Vet Microbiol. 2004; 101: 199-208.
7. Reina R, Berriatua E, Lujan L, Juste R, Sanchez A, de Andres D, Amorena B. Prevention strategies against small ruminant lentiviruses: An update. Vet J. 2009; 182: 31-37.

8. Fisher JW, Menzies PI. Cost of a Maedi Visna Flock Certification Program and the Changes in Productivity and Economic Return. Sheep \& Goat Res J. 2005; 20: 17-24.

9. Ganter M. Veterinary consultancy and health schemes in sheep: Experiences and reflections from a local German outlook. Small Ruminant Res. 2008; 76: 55-67.

10. Brodie S, Concha-Bermejillo A, Snowder G, Demartini J. Current concepts in the epizootiology, diagnosis and economic importance of ovine progressive pneumonia in North America. Small Ruminant Res. 1998; 27: 1-17.

11. Straub O. Maedi-visna virus infection in sheep. History and present knowledge. Comp Immune Microbiol Infec Dis. 2004; 27: 1-5.

12. Sigurdsson B, Palsson PA, Tryggvadottir A. Transmission experiments with maedi. J Infect Dis. 1953; 93: 166-175

13. Houwers DJ, Van der Molen, EJ. A five year serological survey of natural transmission of maedi-visna virus in flock of completed with postmortem investigation. J Vet Med. 1987; 34: 421-431.

14. Junkuszew A, Lipecka Cz, Gruszecki TM, Kuźmak J, Bojar W, Olech M, at al. Maedi-visna virus (MVV) in sheep flocks - the risks and scale of the problem. Animal Production Review. 2010; 9: 22-26.

15. Leginagoikoa I, Juste RA, Barandika J, Amorena B, De Andres D, Lujan L, Badiola J, Berriatua E. Extensive rearing hinders maedi-visna virus (MVV) infection in sheep. Vet Res. 2006; 37: 767-778.

16. Cochran WG. Sampling Techniques, 3rd Edition, Wiley. 1977.

17. Stevenson M. An Introduction to Veterinary Epidemiology. EpiCentre, IVABS, Massey University, Palmerston North, New Zealand. 2006; 1- 90.

18. Lohr SL. Sampling: Design and Analysis. Second edition. Cengage Learning Inc. Boston, 2009; pp 608.

19. Stevenson M, Heuer C. Functions for analysing epidemiological data. Package 'epiR'. EpiCentre, IVABS, Massey University, Palmerston North, New Zealand. 2012; 1-74.

20. Rothman KJ. Epidemiology An Introduction. Oxford University Press, London. 2002; 130-143.

21. Jewell NP. Statistics for Epidemiology. Chapman \& Hall/CRC. London. $2004 ; 84-85$.

22. Keen J, Hungerford L, Wittum T, Kwang J, Littledike ED. Rick factors for seroprevalence of ovine lentivirus in breeding ewe flocks in Nebraska USA. Prev Vet Med. 1997; 30: 81-94.

23. Dungu B, Vorster J, Bath GF, Verwoerd DW. The effect of a natural maedi-visna virus infection on the productivity of South African sheep Onderstepoort. J Vet Res. 2000; 67: 87-96.

24. Andersen CI, von Essen SG, Smith LM., Spencer J, Jolie R, Donham KJ. Respiratory symptoms and airway obstruction in swine veterinarians: A persistent problem. Am J Ind Med. 2004; 46: 386-392.

25. Peterhans E, Greenland T, Badiola J, Harkiss G, Bertoni G, Amorena $\mathrm{B}$, at al. Routes of transmission and consequences of small ruminant lentiviruses (SRLVs) infection and eradication schemes. Vet Res. 2004; 35: 257-274

26. Junkuszew A, Milerski M, Bojar W, Szczepaniak K, Le Scouarnec J, Tomczuk K, at al. Effect of various antiparasitic treatments on lamb growth and mortality. Small Ruminant Res. 2015; 123: 305-312.

27. Papanastasiou DK, Fidaros D, Bartzanas T, Kittas C. Monitoring particulate matter levels and climate conditions in a Greek sheep and goat livestock building. Environ Monit Assess. 2011; 183: 285-296.

28. Cambra-López M, Aarnink AJA, Zhao Y, Calvet S, Torres AG. Airborne particulate matter from livestock production systems: A review of an air pollution problem. Environ Pollut. 2010; 158: 1-17.

29. Bakutis B, Monstviliene E, Januskeviciene G. Analyses of airborne contamination with bacteria, endotoxins and dust in livestock barns and poultry houses. Acta Vet Brno. 2004; 73: 283-289.

30. Razote EB, Maghirang RG, Seitz LM, Jeon IJ. Characterization of volatile organic compounds on airborne dust in a swine finishing barn. T ASAE. 2004; 47: 1231-1238.

31. Melbostad E, Eduard W, Magnus P. Chronic bronchitis in farmers. Scand J Work Env Hea. 1997; 23: 271-280.

32. Radon K, Weber C, Iversen M, Danuser B, Pedersen S, Nowak D. Exposure assessment and lung function in pig and poultry farmers. Occup Environ Med. 2001; 58: 405-410.

33. Danuser B, Weber C, Künzli N, Schindler C, Nowak D. Respiratory symptoms in Swiss farmers: An epidemiological study of risk factors. Am J Ind Med. 2001; 39: 410-418.

34. Donham KJ. Association of environmental air contaminants with disease and productivity in swine. Am J Vet Res 1991; 52: 1723- 1730. 
35. Valavanidis A, Fiotakis K, Vlachogianni T. Airborne particulate matter and human health: toxicological assessment and importance of size and composition of particles for oxidative damage and carcinogenic mechanisms. J Environ Sci Heal C. 2008; 26: 339-362.

36. Doig, PA, Willoughby DVM. Response of swine to atmospheric ammonia and organic dust. JAVMA-J Am Vet Med A. 1971; 159(11): $1353-1361$.

37. Cox CS, Wathes CM, Bioaerosols Handbook. New York: Lewis. 1995.

38. Takai H, Pedersen S, Johnsen JO, Metz JHM, Groot Koerkamp PWG, Uenk GH, et al. Concentrations and emissions of airborne dust in livestock buildings in northern Europe. J Agr Eng Res. 1998; 70: 59-77.
39. Seppänen O, Kurnitski J. Moisture control and ventilation. In: WHO Guidelines for Indoor Air Quality -Dampness and Mould. Geneva: World Health Organization. 2009; 31-61.

40. Bojar W, Junkuszew A. The ecological consciousness of the individuals who use the products containing asbestos in the rual households presented on the case study from three localities within Serokomla municipality. In: Ewa Bojar et al, editors. Environmental aspects of regional development: asbestos regional management - diagnosis and perspectives. Toruń: TNOiK. 2010; 81-90.

41. Wagner JC, Berry G, Skidmore JW, Timbrell V. 1974. The Effects of the Inhalation of Asbestos in Rats. Br J Cancer. 1974; 29(3): 252-269. 